\title{
The role of cytokines and cortisol in the non-thyroidal illness syndrome following acute myocardial infarction
}

\author{
Helen Karga ${ }^{1}$, Panayotis Papaioannou ${ }^{2}$, Kyriaki Venetsanou ${ }^{1}$, Fotini Papandroulaki ${ }^{1}$, Lazaros Karaloizos $^{1}$, \\ Garyphallia Papaioannou ${ }^{1}$ and Peter Papapetrou ${ }^{1}$ \\ ${ }^{1}$ Endocrine Unit, Alexandra Hospital, Vas. Sofias and Lourou Str., Athens 115 28, Greece and ${ }^{2}$ Cardiac Unit, 1st Hospital, Institute of Social Security, \\ Zaimi End Str., Melissia, Attiki 15127, Greece \\ (Correspondence should be addressed to H Karga; Fax: +3018064 524)
}

\begin{abstract}
Objective: A number of different hormone changes have been described during the acute myocardial infarction (AMI), including those of the non-thyroidal illness syndrome (NTIS).

Design and methods: We assessed the alterations of serum thyroid hormones, cytokines and cortisol levels in 30 patients with a first episode of AMI 4, 24, $48 \mathrm{~h}$ and 10 days $(240 \mathrm{~h})$ after the onset of the chest pain and we investigated the possible relationship of these alterations with the severity of AMI. Results: Fifteen patients had left ventricular ejection fraction (LVEF) $\leq 50 \%$ (group I) and 15 patients had LVEF $>50 \%$ (group II). A transient decrease of total tri-iodothyronine $\left(\mathrm{T}_{3}\right)$, more prominent in group I $(P<0.05$, $t$-test $)$ with a concomitant rise of reverse $\mathrm{T}_{3}\left(\mathrm{rT}_{3}\right)$ occurred at $24 \mathrm{~h}$. Total thyroxine $\left(\mathrm{T}_{4}\right)$, free $\mathrm{T}_{4}\left(\mathrm{FT}_{4}\right)$ and free $\mathrm{T}_{4}$ index did not change significantly, but tended to be higher in group I patients, whereas TSH significantly increased in group II at $48 \mathrm{~h}$. Interleukin-6 (IL-6) increased significantly at $24 \mathrm{~h}$ only in group I and declined thereafter $(24 \mathrm{vs} 240 \mathrm{~h}, P<0.001)$ and this temporal change of IL-6 was associated with similar changes of creatine phosphokinase and creatine kinase isoenzyme MB (CK-MB). Tumor necrosis factor- $\alpha$ and IL- $1 \beta$ remained low in both groups. Cortisol was higher at $4 \mathrm{~h}$ and in 12 patients was above the normal values. Negative correlation was found between LVEF and IL-6 $(P<0.001)$, whereas $\mathrm{T}_{3}, \mathrm{~T}_{4}$ or cortisol levels were not correlated with the LVEF. Conclusions: Our data indicate that NTIS, in association with increase of IL-6, occurs in the early postinfarction period. In the NTIS following AMI the high level of IL-6 is the best predictor, among several parameters, of the severity of AMI as assessed by the LVEF and the rise of CK-MB.
\end{abstract}

European Journal of Endocrinology 142 236-242

\section{Introduction}

Alterations in circulating thyroid hormones under severe illness or stressful conditions are referred to as non-thyroidal illness syndrome (NTIS) and are more prominent in patients hospitalized in intensive care units $(1,2)$. These changes are related mainly to the inhibition of the $5^{\prime}$-monodeiodinase activity that leads to the decreased conversion of thyroxine $\left(\mathrm{T}_{4}\right)$ to triiodothyronine $\left(\mathrm{T}_{3}\right)$ in peripheral tissues, but other mechanisms may also be responsible for this syndrome (3). Recently, several proinflammatory cytokines which are elevated during the acute phase response have been implicated in the pathogenesis of the NTIS, although their role is still unclear $(2-4)$. Cytokines are products of immune response acting not only as local factors but also as systemic hormones affecting the function of different endocrine glands such as pituitary or thyroid $(4,5)$.

Acute myocardial infarction (AMI) may be associated with a number of endocrine alterations, including those of the NTIS $(1,6,7)$ which reflect the acute hormone response to stress and trauma. A transient decrease in $\mathrm{T}_{3}$ and increase in reverse $(\mathrm{r}) \mathrm{T}_{3}$ occurs within the first $24 \mathrm{~h}$, reaching the highest degree on the third day after the attack (1). The decreased nutrition during the first days of the myocardial infarct, the increased levels of serum cortisol and circulating free fatty acids or free radicals are some of the factors which may contribute to the $5^{\prime}$-monodeiodinase inhibition (3). Less prominent are the alterations of $\mathrm{T}_{4}$ and thyrotropin (TSH) which appear to be non-significantly changed in most of the patients with acute myocardial infarct (1). On the other hand, the association between serum levels of cytokines and myocardial ischemia and injury is under investigation. It is known from several studies that several cytokines can be found elevated in patients with cardiac ischemia or AMI (7-9). From in vitro studies it is of particular interest that ischemic myocytes produce cytokines such as interleukin-6 (IL-6) and its synthesis 
is accelerated by reperfusion (10). Interleukin- 6 seemed to be an important cytokine produced by the injured myocytes in a study of 15 patients with AMI (11), and strong negative correlation between serum IL-6 concentration and left ventricular ejection fraction (LVEF) has been demonstrated (12). Similar observations have been made by studying tumor necrosis factor- $\alpha$ (TNF- $\alpha$ ), IL- $1 \alpha$ and soluble IL- 2 receptor (sIL-2-R) which were found to be significantly elevated in AMI, with the highest levels noted in the most severe and complicated cases of myocardial infarction $(9,13)$.

In the present work we investigated the relationships between the changes of the thyroid hormones, cortisol and cytokines in patients admitted to a coronary care unit for a first episode of AMI. The temporal development of these changes and the possible correlation with the severity of the AMI were studied.

\section{Materials and methods}

Thirty patients with a first episode of AMI who were admitted to the coronary care unit 1-6 h (mean $4 \mathrm{~h}$ ) after the onset of pain were prospectively studied. The diagnosis of the AMI was based on the history of prolonged chest pain (>30 min) and it was confirmed by typical electrocardiogram changes and elevation in serum creatine phosphokinase (CPK) levels, in creatine kinase isoenzyme $\mathrm{MB}(\mathrm{CK}-\mathrm{MB})$ and positive troponin I test. The mean age of the patients $(18$ men and 12 women) was $60 \pm 8$ years, range 50-72 years. Exclusion criteria from the study were previous myocardial infarction, known cardiac disease, known thyroid gland abnormalities, chronic illness and use of medication before the admission. To minimize variations of the results only those patients were chosen who received standardized treatment for AMI such as thrombolysis, heparin, aspirin and nitrates (without any contraindication for this kind of treatment) and who were on a similar diet during the hospitalization. Blood samples were taken at the time of the admission, before any treatment $(4 \mathrm{~h})$, and at 24,48 and $240 \mathrm{~h}$ after the beginning of the chest pain. After the separation, the sera were kept frozen $\left(-20^{\circ} \mathrm{C}\right)$ until the day of the assay. The patients gave their informed consent to participate in this study, which was approved by the scientific committee of the hospital.

\section{Measurement of hormones and cytokines}

All samples were run in duplicate and the mean value of the results are reported. All the samples of an individual subject were run in the same assay to minimize the inter-assay variation. Serum total $\mathrm{T}_{4}$ and $\mathrm{T}_{3}$ were determined using competitive RIA technique (AmerlexM, Amersham, Bucks, UK; Milano, Italy). The normal range (NR) values for our adult population are 62$165 \mathrm{nmol} / \mathrm{l}$ for $\mathrm{T}_{4}$ with intra-assay coefficient of variation $(\mathrm{CV}) 2.6 \%$ at the $84.1 \mathrm{nmol} / \mathrm{l}$ level; for $\mathrm{T}_{3} \mathrm{NR}$ is $0.8-2.7 \mathrm{nmol} / \mathrm{l}$, and CV $1.5 \%$ at the $1.48 \mathrm{nmol} / \mathrm{l}$ level. Serum free $(\mathrm{F}) \mathrm{T}_{4}$ was measured by two different methods (both from Nichols Institute Diagnostics, San Juan Capistrano, CA, USA): (1) a direct equilibrium dialysis method $\left(\mathrm{FT}_{4} \mathrm{Eq}\right)$ with NR $10.3-34.7 \mathrm{pmol} / \mathrm{l}$ and with $\mathrm{CV}$ $10.7 \%$ at $12 \mathrm{pmol} / \mathrm{l}$; (2) by a one-site chemiluminescence immunometric assay $\left(\mathrm{FT}_{4} \mathrm{Ch}\right)$ with $\mathrm{NR} 9-23 \mathrm{pmol} / \mathrm{l}$ and $\mathrm{CV} 5.6 \%$ for the $\mathrm{FT}_{4} \mathrm{Ch}$ value of $17 \mathrm{pmol} / \mathrm{l}$. For the determination of $\mathrm{TSH}$, a third generation two-site chemiluminescence immunoassay was used (Nichols Institute Diagnostics, Nijmegen, The Netherlands) with NR $0.4-3 \mu \mathrm{U} / \mathrm{ml}$, with $\mathrm{CV} 4.8 \%$ for a TSH value of $1.28 \mu \mathrm{U} / \mathrm{ml}$. Serum $\mathrm{T}_{3}$ uptake $\left(\mathrm{T}_{3} \mathrm{U}\right)$ and cortisol were measured by a solid phase RIA (Coat-A-Count, Diagnostic Products Corporation, Los Angeles, CA, USA). For $\mathrm{T}_{3} \mathrm{U}$ the NR is $25-37 \%$ and $\mathrm{CV} 1.8 \%$ at the $30.2 \%$ value. For cortisol the NR is $138-690 \mathrm{nmol} / \mathrm{l}$, and CV $4 \%$ for the value of $331 \mathrm{nmol} / \mathrm{l}$. Free $\mathrm{T}_{4}$ index $\left(\mathrm{FT}_{4} \mathrm{I}\right)$ was calculated by multiplying the total $\mathrm{T}_{4}$ concentration by the $\mathrm{T}_{3} \mathrm{U} ; \mathrm{rT}_{3}$ was measured by RIA (Biodata S.p.A., Roma, Italy) with NR $0.135-0.539 \mathrm{nmol} / \mathrm{l}$ and $\mathrm{CV}$ $8.54 \%$ at $0.369 \mathrm{nmol} / \mathrm{l}$. Serum IL- $1 \alpha$, TNF- $\alpha$ and IL-6 were measured by an ultrasensitive solid phase 'sandwich' ELISA (Cytoscreen, Biosourse, Camazillo, CA, USA). The NR of TNF- $\alpha$ is from non-detectable to $22 \mathrm{pg} /$ $\mathrm{ml}$ with CV $4.8 \%$ for a level of $11.9 \mathrm{pg} / \mathrm{ml}$, for IL- $1 \beta$ from non-detectable to $10 \mathrm{pg} / \mathrm{ml}$ with CV $3.01 \%$ for the level of 2.66 , and for IL- 6 from 0.1 to $8.5 \mathrm{pg} / \mathrm{ml}$ with CV $6 \%$ for the level of $5.17 \mathrm{pg} / \mathrm{ml}$.

\section{Cardiac echocardiogram, measurement of CPK, CK-MB and troponin I test}

Left ventricular ejection fraction was determined by two-dimensional echocardiogram with a commercially available imaging system (Hewlett-Packard, SONOS 1000, Andover, MA, USA) within 2-7 days after the AMI. For the measurement of CPK a commercial kit was used from DMA Inc. (Arlington, TX, USA) with expected normal values $7-114 \mathrm{U} / \mathrm{l}$ at $30^{\circ} \mathrm{C}$ and $\mathrm{CV} 2.7 \%$ at $104 \mathrm{IU} / \mathrm{l}$, and for CK-MB a kit from Deagle Diagnostics was used (Desoto, TX, USA), normal values $0-24$ IU/l at $37^{\circ} \mathrm{C}$ with a $\mathrm{CV} 3.2 \%$ at a level of $17.8 \mathrm{IU} / \mathrm{l}$. For the troponin I test the Cardiac Status kit was used (PBM, Princeton Biomedich Corp., Princeton, NJ, USA).

\section{Statistics}

All results are expressed as means \pm s.E.M. and a twotailed $P$ value of less than 0.05 was accepted as significant. Comparison of changes of the variables over time and/or within groups was performed by twotailed paired Student's $t$-test. Linear regression analysis was carried out for the evaluation of the relationships between the different variables. Undetectable cytokine concentrations were taken as $50 \%$ of the detection limit, for the scope of calculations. 


\section{Results}

The 30 patients with a first episode of AMI included in the study were divided into two groups according to their LVEF. An LVEF of $50 \%$ was used as a cutoff to identify patients with better or poorer prognosis (14). Group I included 15 patients (12 smokers and 3 nonsmokers) whose LVEF was $\leq 50 \%$, and group II included 15 patients (13 smokers and 2 non-smokers) with LVEF $>50 \%$. The characteristics of the two patients groups are shown in Table 1. Figure 1 displays the time course (mean \pm s.E.M.) in thyroid function tests, serum IL-6 and cortisol levels (on 4, 24, 48 and 240 h) of the post-infarction period. Initially, the data were compared between the two groups. Correlations between two variables were assessed using the values of the two groups at the various times combined. Two patients died during the study period. One patient died from heart failure and the other one from hemorrhagic stroke. No significant difference was found in the mean age of the two groups of subjects ( $60 \pm 8$ years), in diastolic blood pressure $(88.8 \pm 3.5$ vs $86.9 \pm 4 \mathrm{~mm} \mathrm{Hg})$, in systolic blood pressure $(152.5 \pm 8.5$ vs $151.5 \pm 9.8 \mathrm{~mm} \mathrm{Hg})$, in the levels of total cholesterol $(248 \pm 24$ vs $243 \pm$ $23 \mathrm{mg} / \mathrm{dl}$ ) and triglycerides (166 $\pm 33 \mathrm{vs} 172 \pm 31 \mathrm{mg} /$ dl), whereas in group I LVEF was significantly lower than in those of group II $(42.0 \pm 2.2$ vs $57.0 \pm 3.0 \%$, $P<0.001$ ) (Table 1).

\section{CPK and CK-MB}

In both groups a marked increase in serum CPK and CK$\mathrm{MB}$, as expected, was observed $24 \mathrm{~h}$ after the onset of the chest pain followed by a rapid decrease thereafter (Table 1). The concentrations of CPK and CK-MB were significantly greater in group I than in group II $(P<0.05)$.

\section{Thyroid function tests}

At the time of the peak of serum enzymes (24 h after the onset of pain) serum $\mathrm{T}_{3}$ fell in both groups (Fig. 1A), but only in group I was the decrease significant $(P<0.05)$. Serum $\mathrm{T}_{3}$ increased gradually within the subsequent hours, without significant differences between the values within the two groups at any point of time. Individual analysis showed that although

Table 1 Characteristics of the AMI subjects at the four different points of time. Values shown are means \pm S.E.M.

\begin{tabular}{|c|c|c|c|c|c|}
\hline & & $4 h$ & $24 \mathrm{~h}$ & $48 h$ & $240 \mathrm{~h}$ \\
\hline \multicolumn{6}{|l|}{ Group I $(n=15)$} \\
\hline Age (years) & $60 \pm 8$ & & & & \\
\hline LVEF (\%) & $42.0 \pm 2.2^{a}$ & & & & \\
\hline CPK (IU/I) & & $347 \pm 88$ & $1828 \pm 276^{b}$ & $683 \pm 145$ & $174 \pm 37$ \\
\hline CK-MB (IU/I) & & $49.0 \pm 10$ & $207 \pm 26^{c}$ & $67.20 \pm 12$ & $26.58 \pm 2.81$ \\
\hline $\mathrm{FT}_{4} \mathrm{Eq}(\mathrm{pmol} / \mathrm{l})$ & & $26.9 \pm 1.58$ & $27.0 \pm 1.61$ & $27.45 \pm 1.94$ & $24.79 \pm 1.93$ \\
\hline $\mathrm{FT}_{4}(\mathrm{pmol} / \mathrm{l})$ & & $20.0 \pm 1.06$ & $19.7 \pm 1.14$ & $20.82 \pm 1.06$ & $20.52 \pm 0.96$ \\
\hline $\mathrm{T}_{4}(\mathrm{nmol} / \mathrm{l})$ & & $130.8 \pm 7.36$ & $133.6 \pm 7.05$ & $146.27 \pm 8.02$ & $143.51 \pm 7.52$ \\
\hline $\mathrm{FT}_{4} \mathrm{I}$ & & $4020 \pm 220$ & $3660 \pm 3.230$ & $4155 \pm 202$ & $4198 \pm 208$ \\
\hline $\mathrm{TSH}(\mathrm{mIU} / \mathrm{l})$ & & $0.98 \pm 0.13$ & $1.06 \pm 0.13$ & $1.29 \pm 0.15$ & $1.03 \pm 0.13$ \\
\hline $\mathrm{T}_{3}(\mathrm{nmol} / \mathrm{l})$ & & $1.62 \pm 0.08$ & $1.36 \pm 0.07^{d}$ & $1.45 \pm 0.9$ & $1.45 \pm 0.06$ \\
\hline $\mathrm{rT}_{3}(\mathrm{nmol} / \mathrm{l})$ & & $0.380 \pm 0.04$ & $0.491 \pm 0.06$ & $0.474 \pm 0.07$ & $0.405 \pm 0.04$ \\
\hline Cortisol (nmol/l) & & $785 \pm 137$ & $583 \pm 73$ & $559 \pm 50$ & $493 \pm 56$ \\
\hline $\mathrm{TNF}-\alpha(\mathrm{pg} / \mathrm{ml})$ & & $0.477 \pm 0.07$ & $0.350 \pm 0.07$ & $0.400 \pm 0.06$ & $0.290 \pm 0.06$ \\
\hline $\mathrm{IL}-1 \beta(\mathrm{pg} / \mathrm{ml})$ & & $0.407 \pm 0.08$ & $0.429 \pm 0.02$ & $0.377 \pm 0.04$ & $0.364 \pm 0.02$ \\
\hline IL-6 (pg/ml) & & $5.60 \pm 0.98$ & $10.78 \pm 1.84$ & $6.11 \pm 1.33$ & $2.83 \pm 0.53$ \\
\hline $\mathrm{rT}_{3} / \mathrm{T}_{3}$ ratio & & $0.263 \pm 0.03$ & $0.348 \pm 0.06$ & $0.237 \pm 0.02$ & $0.258 \pm 0.03$ \\
\hline \multicolumn{6}{|l|}{ Group II $(n=15)$} \\
\hline Age (years) & $60 \pm 8$ & & & & \\
\hline LVEF (\%) & $57.0 \pm 3.0$ & & & & \\
\hline CPK (IU/I) & & $233 \pm 59$ & $1012 \pm 176$ & $279 \pm 57$ & $104 \pm 16$ \\
\hline CK-MB (IU/I) & & $31 \pm 8$ & $116 \pm 20$ & $31 \pm 4$ & $16 \pm 3$ \\
\hline $\mathrm{FT}_{4} \mathrm{Eq}(\mathrm{pmol} / \mathrm{l})$ & & $21.85 \pm 1.81$ & $21.55 \pm 1.78$ & $22.79 \pm 1.07$ & $22.35 \pm 1.34$ \\
\hline $\mathrm{FT}_{4} \mathrm{El}(\mathrm{pmol} / \mathrm{l})$ & & $17.32 \pm 0.47$ & $16.71 \pm 0.43$ & $18.48 \pm 0.44$ & $19.32 \pm 0.64$ \\
\hline $\mathrm{T}_{4}(\mathrm{nmol} / \mathrm{l})$ & & $118.4 \pm 8.6$ & $116.91 \pm 8.8$ & $131.33 \pm 5.7$ & $137.7 \pm 8.9$ \\
\hline $\mathrm{FT}_{4} \mathrm{I}$ & & $3522 \pm 245$ & $3315 \pm 213$ & $3760 \pm 229$ & $3883 \pm 295$ \\
\hline TSH (mIU/l) & & $0.824 \pm 0.13$ & $1.07 \pm 0.19$ & $1.48 \pm 0.18^{\mathrm{e}}$ & $1.33 \pm 0.17$ \\
\hline $\mathrm{T}_{3}(\mathrm{nmol} / \mathrm{l})$ & & $1.41 \pm 0.07$ & $1.32 \pm 0.06$ & $1.50 \pm 0.07$ & $1.52 \pm 0.8$ \\
\hline $\mathrm{rT}_{3}(\mathrm{nmol} / \mathrm{l})$ & & $0.359 \pm 0.03$ & $0.369 \pm 0.3$ & $0.348 \pm 0.07$ & $0.340 \pm 0.06$ \\
\hline Cortisol (nmol/l) & & $557 \pm 82$ & $452 \pm 54$ & $503 \pm 39$ & $447 \pm 25$ \\
\hline $\mathrm{TNF}-\alpha(\mathrm{pg} / \mathrm{ml})$ & & $0.460 \pm 0.12$ & $0.500 \pm 0.24$ & $0.322 \pm 0.05$ & $0.475 \pm 0.23$ \\
\hline $\mathrm{IL}-1 \beta(\mathrm{pg} / \mathrm{ml})$ & & $0.430 \pm 0.07$ & $0.414 \pm 0.10$ & $0.374 \pm 0.3$ & $0.473 \pm 0.05$ \\
\hline IL-6 (pg/ml) & & $4.04 \pm 0.59$ & $6.05 \pm 1.56$ & $5.06 \pm 1.21$ & $3.79 \pm 0.75$ \\
\hline $\mathrm{rT}_{3} / \mathrm{T}_{3}$ ratio & & $0.294 \pm 0.05$ & $0.281 \pm 0.02$ & $0.242 \pm 0.06$ & $0.233 \pm 0.01$ \\
\hline
\end{tabular}

Statistical differences evaluated by Student's $t$-test; ${ }^{a} P<0.001$ (group I vs group II), ${ }^{\text {b }} P<0.0001$ (24 vs $4 \mathrm{~h}$ ), ${ }^{c} P<0.001$ (24 vs $\left.4 \mathrm{~h}\right),{ }^{\mathrm{d}} P<0.05(24$ vs $4 \mathrm{~h}),{ }^{\mathrm{e}} P<0.05(48$ vs $4 \mathrm{~h})$. 


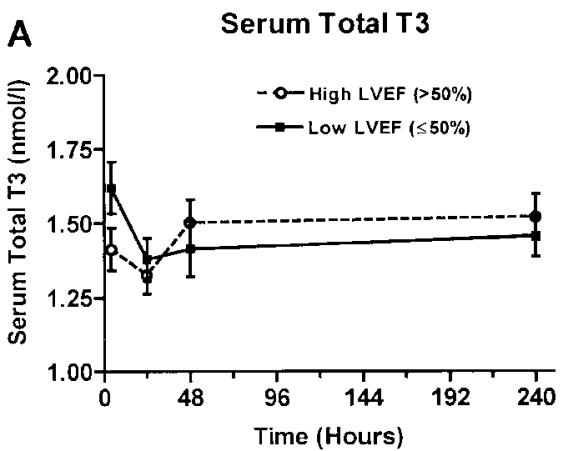

D Serum Free T4 (Equil.Dial.)
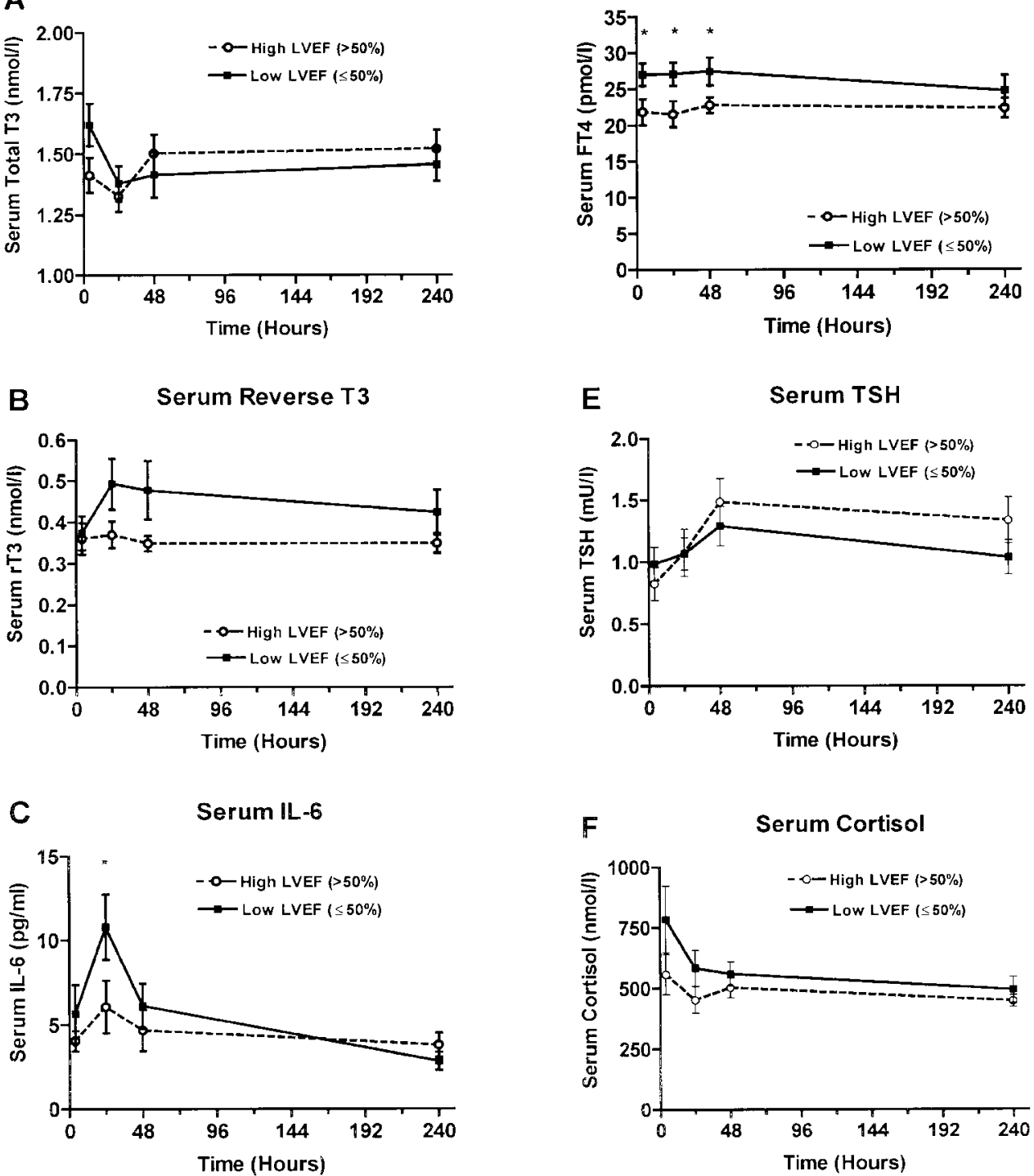

Figure 1 Changes in serum $\mathrm{T}_{3}$ levels $(\mathrm{A}), \mathrm{rT}_{3}(\mathrm{~B}), \mathrm{IL}-6(\mathrm{C}), \mathrm{FT}_{4}$ by equilibrium dialysis (D), TSH $(\mathrm{E})$ and cortisol $(\mathrm{F})$ at $4,24,48$ and $240 \mathrm{~h}$ after the onset of chest pain in patients with AMI. Values shown are the means \pm S.E.M. Continuous lines represent patients with LVEF $\leq 50 \%$ and dotted lines represent patients with $\mathrm{LVEF} \geq 50 \%$. At a given time, an asterisk indicates a significant difference between the two groups.

a transient decrease of serum $\mathrm{T}_{3}$ was found in $22 / 30$ (73\%) patients of both groups, only $4 / 30(13 \%)$ declined below the normal range $(0.77 \pm 0.01 \mathrm{nmol} / \mathrm{l})$. Three of these patients belonged to group I and one patient belonged to group II. A peak of serum $\mathrm{rT}_{3}$ was shown at $24 \mathrm{~h}$ (Fig. 1B), but it did not reach a statistically significant level, and although in group $\mathrm{I}_{\mathrm{rT}}$ levels were slightly higher, there was not a statistically significant difference between the two groups. The $\mathrm{rT}_{3} /$ $\mathrm{T}_{3}$ ratio did not change significantly, but tended to be higher in group I, $P<0.2$ at $24 \mathrm{~h}$ reflecting the higher $\mathrm{rT}_{3}$ and the lower $\mathrm{T}_{3}$ in these patients. The mean serum $\mathrm{FT}_{4}$ levels, as determined by equilibrium dialysis
(Fig. 1D) and ELISA, showed consistent, almost identical, values by both methods and no significant change during the entire observation period. Interestingly, $\mathrm{FT}_{4}$ levels were significantly higher in group I than in those of group II within the first 4, 24 and $48 \mathrm{~h}$ $(P<0.05)$. An elevation of total $\mathrm{T}_{4}$ towards higher levels in association with a rise of $\mathrm{FT}_{4} \mathrm{I}$ was observed in both groups starting at $48 \mathrm{~h}$ and both parameters remained higher from baseline until the end of the study; there were no significant differences between the corresponding different points of time between the two groups. Serum concentrations of TSH remained within the normal range and did not change significantly in 
group I, whereas in group II they rose significantly at $48 \mathrm{~h}$ until the end of the study $(P<0.05)$ (Fig. 1E).

\section{Cytokines and cortisol}

In both groups the peak mean serum IL-6 occurred at $24 \mathrm{~h}$ after the onset of pain (Fig. 1C) which corresponded to the nadir of $\mathrm{T}_{3}$ levels and to the peak values of $\mathrm{rT}_{3}$, CPK and CK-MB. In group I the rise of IL-6 was statistically significant, $4 \mathrm{~h}$ vs $24 \mathrm{~h}(P<0.05)$ and less pronounced in the patients of group II, $P<0.05$. A subset of 10 patients, 33\% of all subjects (seven from group I and three from group II) had serum IL-6 above the normal range $(17.66 \pm 0.84 \mathrm{pg} / \mathrm{ml})$ and in three of them it remained high until $48 \mathrm{~h}$.

No differences were found in the concentrations of TNF- $\alpha$ and IL- $1 \beta$, either between the groups or between the different sampling times and these indexes remained virtually unchanged, at very low or undetectable levels, throughout the study. Mean serum cortisol levels tended to be elevated slightly above the normal values only in group I at the time of admission, (Fig. 1F), and progressively decreased at $240 \mathrm{~h}(4 \mathrm{~h}$ vs $240 \mathrm{~h}$, $P<0.07)$, but there was no significant difference between the two groups. Interestingly, the two patients who died had very high cortisol levels at the time of admission $(2400.8$ and $1061.5 \mathrm{nmol} / \mathrm{l})$. They also showed the lowest $\mathrm{T}_{3} 24 \mathrm{~h}$ levels $(0.770$ and $0.718 \mathrm{nmol} / \mathrm{l})$ and the highest $\mathrm{rT}_{3} 24 \mathrm{~h}$ levels (1.011 and $1.167 \mathrm{nmol} / \mathrm{l}$ ) in association with the highest IL-6 levels $(23$ and $15 \mathrm{pg} / \mathrm{ml})$ among all patients.

\section{Relations between the different parameters}

Taking the values of the different points of time as a combined group, a significant negative linear correlation was found between IL-6 and $\mathrm{T}_{3}(r=-0.284$, $P<0.001)$, and a positive correlation between IL-6 and $\mathrm{rT}_{3}(r=0.364, P<0.001)$ and IL-6 and $\mathrm{rT}_{3} / \mathrm{T}_{3}$ ratio $(r=0.320, P<0.001)$. Serum IL-6 and LVEF were negatively correlated $(r=-0.381, P<0.001)$ and a strong, but inverse, relationship was also present between IL-6 and CK-MB $(r=0.542, P<0.001)$ (Fig. $2 \mathrm{~A}$ and $\mathrm{B})$. In contrast, $\mathrm{T}_{3}$ was not correlated with LVEF.

\section{Discussion}

The results of this study indicate that serum cortisol was increased in patients with AMI during the first $4 \mathrm{~h}$ of the onset of the chest pain. The characteristic changes of the NTIS were also found to be an early event in our patients and associated with an increase of IL-6, whereas TNF- $\alpha$ and IL- $1 \beta$ were low and unchanged. In addition, using the LVEF as a marker of the severity of AMI (14) it was found that the circulating IL-6 concentrations were best correlated with LVEF rather than with serum $\mathrm{T}_{3}$, thyroxine or cortisol levels.

In AMI, a significant decrease of serum $\mathrm{T}_{3}$ levels and
A
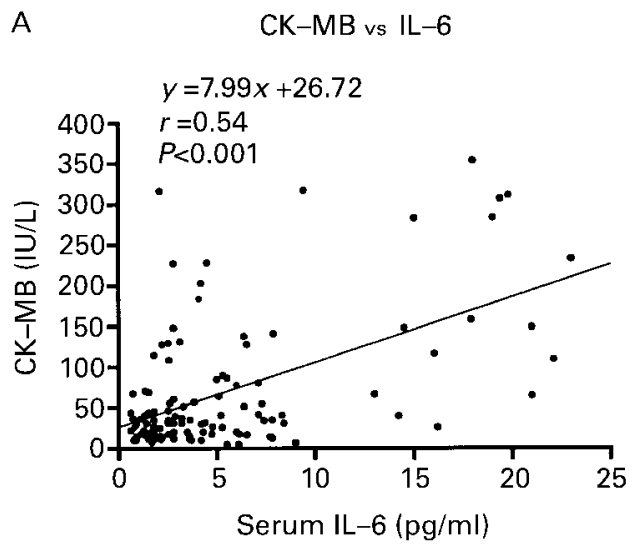

B
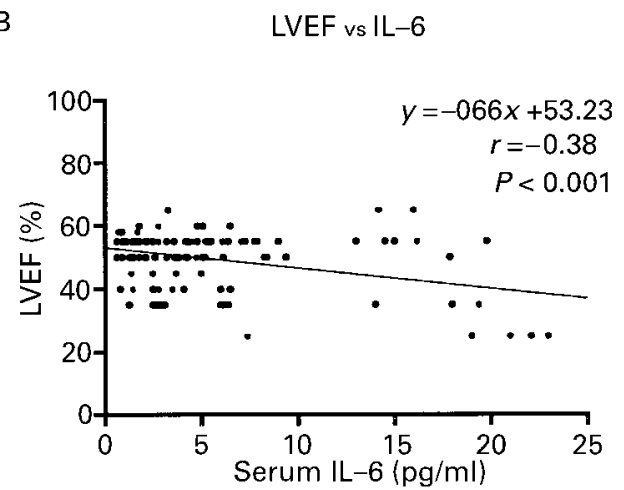

Figure 2 Linear correlations between $(A)$ serum levels of CK-MB and IL-6, and between (B) LVEF and IL-6 in patients with AMI. The values $(n=118)$ at the different points of time were taken as a combined group.

an increase of serum $\mathrm{rT}_{3}$ usually occur at the third postinfarction day, whereas $\mathrm{T}_{4}$ and TSH rarely change (1, 15). In the present study, the lowest serum $T_{3}$ and peak $\mathrm{rT}_{3}$ were found $24 \mathrm{~h}$ after the onset of chest pain at the time of the highest serum CPK/CK-MB and IL-6 levels. It is likely that the early thrombolysis diminished the degree of the acute phase response events and the infarct size (16), and thus inhibited the progression to a severe NTIS. This is also demonstrated by the fact that in only four patients serum $\mathrm{T}_{3}$ decreased below the normal range values and in none of them did $\mathrm{FT}_{4}, \mathrm{~T}_{4}$ or $\mathrm{FT}_{4} \mathrm{I}$ fall to subnormal levels. It could be suggested that because of heparin treatment, $\mathrm{FT}_{4}$ was apparently higher in our patients than it would be without this treatment, particularly when free $\mathrm{T}_{4}$ was measured by equilibrium dialysis (17). For this reason free $\mathrm{T}_{4}$ was also estimated by a second method (ELISA) and the changes were similar. Impairment of thyroxine transportation into tissues or reduced serum clearance rate probably due to low cardiac output from the myocardial dysfunction could explain the 'higher $\mathrm{T}_{4}$ state' in our group I patients (3). The fact that the elevation of TSH preceded the rise of both $\mathrm{T}_{4}$ and $\mathrm{FT}_{4} \mathrm{I}$ and the slight increase of $\mathrm{FT}_{4}$, indicates that these rises were probably caused by TSH. The 
elevation of TSH in association with an increase of $\mathrm{T}_{4}$ has been described in a number of patients with low $\mathrm{T}_{4}$ recovering from critical illness due to a variety of causes, including AMI (18). It is noteworthy that TSH rose significantly in the group II of our patients with the better prognosis, indicating a more rapid recovery phase compared with group I. The alterations of serum $\mathrm{T}_{3}$ and $\mathrm{rT}_{3}$ levels were not correlated with the severity of the AMI, although the decline of serum $\mathrm{T}_{3}$ was more pronounced in patients with lower LVEF (group I).

The concomitant changes and the significant negative correlation of serum IL-6 with serum $\mathrm{T}_{3}$ and the positive correlation with serum $\mathrm{rT}_{3}$, raises again the issue that cytokines may be one of the causative factors of NTIS. In vitro experiments with human thyrocytes or in vivo with rats have shown that TNF- $\alpha$, IL- $1 \beta$, IL- 6 and interferon- $\alpha$ (IFN- $\alpha)$ inhibit several thyroid cell functions (4). Administration of recombinant IL-6 to humans induced significant decrease in serum $\mathrm{T}_{3}$ and TSH concentrations in association with an increase in serum $\mathrm{rT}_{3}$, and no changes in $\mathrm{T}_{4}$ and $\mathrm{FT}_{4}$ concentrations (19). In agreement with this were our findings of a strong positive correlation between IL- 6 and $\mathrm{T}_{3}$, and the negative correlation between IL- 6 and $\mathrm{rT}_{3}$ or $\mathrm{rT}_{3} / \mathrm{T}_{3}$ ratio, although TSH and IL- 6 were not correlated. The very low or undetectable levels of TNF- $\alpha$ and IL-1 $\beta$ suggest that both these cytokines probably played a minor role in the development of the NTIS in our patients. The possibility that we may have missed a transient TNF- $\alpha$ and IL- $1 \beta$ elevation, which could be sufficient for the development of NTIS, cannot be excluded. The possibility also that TNF- $\alpha$ and IL-1 $\beta$ were eliminated by binding rapidly to their receptors cannot be ruled out. On the other hand, in our cases the early elevation of IL- 6 may have inhibited the secretion of TNF- $\alpha$ and IL- $1 \beta$. The possibility also exists that the NTIS and the increase of IL-6 are independent events reflecting the reaction to stress and inflammation. Hypoxia induces the synthesis of IL-6 from endothelial cells and cardiac myocytes (10). In our cases, it is likely that IL-6 was secreted from cardiac tissue with an exacerbation of the phenomenon after the thrombolysis (10) since it followed the temporal pattern of CPK and CK-MB concentrations and seemed also to be independent of cortisol concentrations. The magnitude of the IL-6 rise in AMI has been described to possess a prognostic value (14) and in agreement with this, it not only was a strong correlation between IL- 6 and LVEF or CK-MB found in our patients, but in group I subjects the mean IL-6 levels were significantly higher compared with those of group II.

The relatively higher mean cortisol levels in our patients during the first $4 \mathrm{~h}$ of the onset of AMI could explain the slightly lower TSH, although we did not find a negative relationship between cortisol and TSH. It is likely that the transient increase of cortisol was not sufficient to suppress TSH to very low levels and, indeed, the tendency for a rapid increase of TSH indicates the absence of central hypothyroidism. The elevated levels of endogenous cortisol could also be responsible for the alterations of $\mathrm{T}_{3}$ and $\mathrm{rT}_{3}$ acting at a peripheral level. However, although a strong positive correlation between serum cortisol and $\mathrm{rT}_{3}$ levels was found, there was not a significant correlation with $\mathrm{T}_{3}$. In our patients, serum cortisol levels at the time of admission tended to be higher in patients of group I than in those of group II, and it is noteworthy that the two patients who died had persistent hypercortisolemia with the lowest $\mathrm{T}_{3}$ and the highest $\mathrm{rT}_{3}$ among all patients, although the TSH was not suppressed. However, the cortisol levels did not correlate with CPK, CK-MB or LVEF, indicators of the infarct size and the severity of the AMI (20).

In conclusion, we found that AMI induces early alterations in thyroid function tests which resemble those found in the NTIS in association with marked increase of serum IL-6, whereas TNF- $\alpha$ and IL-1 seemed not to be changed significantly. An early and transient increase of serum cortisol may also be associated with the AMI. Among all parameters studied, serum IL-6 concentration was the best marker for the left ventricular dysfunction which could be used as an early marker for the severity of AMI in cardiological practice.

\section{References}

1 Wartofsky L \& Burman K. Alterations in thyroid function in patients with systemic illness: the 'Euthyroid Sick Syndrome'. Endocrine Reviews 19823 164-217.

2 De Groot L. Dangerous dogmas in medicine; the nonthyroidal illness syndrome. Journal of Clinical Endocrinology and Metabolism $199984151-164$.

3 Chopra I. Euthyroid sick syndrome: is it a misnomer? Journal of Clinical Endocrinology and Metabolism 199782 329-334.

4 Bartalena L, Bogazzi F, Brogioni S, Grasso L \& Martino E. Role of cytokine in the pathogenesis of the euthyroid sick syndrome. European Journal of Endocrinology 1998138 603-614.

5 Imura H, Fukata J \& Mori T. Cytokines and endocrine function: an interaction between the immune and neuroendocrine systems. Clinical Endocrinology 199135 107-115.

6 Eber B, Schumacher M, Langsteger W, Zweiker R, Fruhwald F et al. Changes in thyroid hormone parameters after acute myocardial infarction. Cardiology 199586 152-156.

7 Maury C \& Teppo A. Circulating tumor necrosis factor- $\alpha$ (cachectin) in myocardial infarction. Journal of Internal Medicine $1989225333-336$.

8 Neuman FJ, Ott I, Gawaz M, Richardt G, Holzapfel H, Jochum M et al. Cardiac release of cytokines and inflammatory responses in acute myocardial infarction. Circulation 199592 748-755.

9 Marx N, Neuman FJ, Ott I, Gawaz M, Koch W, Pinkau T et al. Induction of cytokine expression in leukocytes in acute myocardial infarction. Journal of the American College of Cardiology 1997 30 165-170.

10 Kukielka G, Smith W, Manning A, Youker K, Michael L \& Entman M. Induction of interleukin-6 synthesis in the myocardium. Potential role in postreperfusion inflammatory injury. Circulation $1995921866-1875$.

11 Sawa Y, Ischikawa H, Kagisaki K, Ohata T \& Matsuda H. Interleukin-6 derived from hypoxic myocytes promotes neutrophil-mediated reperfusion injury in myocardium. Journal of Thoracic and Cardiovascular Surgery 1998116 511-517. 
12 Cruickshank A, Oldroyd K \& Cobbe S. Serum interleukin-6 in suspected myocardial infarction. Lancet 1994343974.

13 Blum A, Sclarovsky S, Rehavia E \& Shohat B. Levels of Tlymphocyte subpopulations, interleukin-1 $\beta$, and interleukin-2 receptor in acute myocardial infarction. American Heart Journal 1994127 1226-1230.

14 Emond M, Mock M, Davis K, Fisher L, Holmes D, Chaitman B et al. Long-term survival of medically treated patients in the coronary artery surgery study (CASS) registry. Circulation $1994902645-$ 2657.

15 Kaplan M, Schimmel M \& Utiger R. Changes in serum 3,3', $5^{\prime}$ triiodothyronine (reverse $\mathrm{T}_{3}$ ) concentrations with altered thyroid hormone secretion and metabolism. Journal of Clinical Endocrinology and Metabolism 197745 447-456.

16 Bell D, Jackson M, Niccol J, Millar A, Dawes J \& Muir A. Inflammatory response, neutrophil activation, and free radica production after myocardial infarction: effect of thrombolytic treatment. British Heart Journal 199063 82-87.

17 Jaume J, Mendel C, Frost P, Greenspan F \& Laughton C. Extremely low doses of heparine release lipase activity into the plasma and can thereby cause artifactual elevations in the serum-free thyroxine concentration as measured by equilibrium dialysis. Thyroid $1996679-83$.

18 Hamblin PS, Dyer S, Mohr V, Le Grand B, Lim CF, Tuxen D et al. Relationship between thyrotropin and thyroxine changes during recovery from severe hypothyroxinemia of critical illness. Journal of Clinical Endocrinology and Metabolism 198662 717-722.

19 Stouthard JML, van der Poll T, Endert E, Bakker PJM, Veenhof C, Sauerwein $\mathrm{H}$ et al. Effects of acute and chronic interleukin-6 administration on thyroid hormone metabolism in humans. Journal of Clinical Endocrinology and Metabolism 199479 1342-1346.

20 Adams J, Abendschein D \& Jaffe A. Biochemical markers of myocardial injury. Is MB creatine kinase the choice for the 1990s? Circulation $199388750-763$.

Received 2 August 1999

Accepted 12 October 1999 